\title{
PROSPECTS FOR WOOD PRODUCTS TRADE UNDER THE NEW PARTNERSHIP FOR AFRICA'S DEVELOPMENT
}

\author{
${ }^{* 1}$ LARINDE, S. L, ${ }^{2}$ AKANDE, J. A, ${ }^{3}$ AGBEJA, B.O. AND ${ }^{4}$ NTABE, E. \\ ${ }^{1}$ University of Port Harcourt, P.M.B 5323, Port Harcourt, Rivers State \\ ${ }^{2}$ Bowen University, P.M.B 284, Iwo, Osun State \\ ${ }^{3}$ University of Ibadan, Nigeria \\ ${ }^{4}$ University of Dschang, POB 222, Dschang, Cameroon \\ * Corresponding Author
}

\begin{abstract}
This paper evaluates the prospects for the development of inter-and intra-regional wood products trade in the countries of Sub-Sahara Africa using Ghana, Nigeria and Cameroon as case study. A total of 517 wood processing firms comprising 121 in Ghana, 258 in Nigeria and 138 in Cameroon were surveyed through the use of structured questionnaire and physical observation of production site to assess the appropriateness of existing technologies, capacity-building needed for more efficient industrial processing vis-à-vis the technology, environmental and market situations. Result shows that trade among nations in the subSahara region can be strenghtened with the adoption of common policy to secure better deals for the wood products export from this region to markets outside the region. Sub-regional trade arrangement also has a huge potential for creating employment, income and wealth for the populations and states concerned. There is need to direct resources towards the most productive ends; need to conserve foreign exchange through increased diversification of exportable products and domestic production of value added products targetted towards foreign exchange conservation and substitution.
\end{abstract}

Keywords: Wood product, trade, forest industry

\section{INTRODUCTION}

Forest industry is a major production sub-sector in sub-Sahara Africa. Its development is characterized by mechanical processing of timber into sawn wood, veneer and plywood. The industry impacted the rest of the economy by making positive contributions to raw material production and supply for construction, furniture and packaging. Also because they are located in rural areas close to the source of raw materials, they encourage a dissemination of technical skills and help to ease the transition from subsistence to an industrialized economy. Thus, the forest industry contributes greatly to stability of the rural communities and minimizes drift to the over-congested urban areas (Popoola and Adebusoye, 2002). The available timber resource is concentrated in the sub-Sahara Africa whereas the consumption cut across other parts of Africa and beyond. Wood products trades from these timber resources are therefore vital to the economy of the producing countries.

The contribution of forest industries to economic development has been well described by many authors (Westoby 1962; Spears 1966; Omoluabi 1985; Adeyoju 1975 and Popoola 1999). Trade in forest products represents $2 \%$ of Africa's trade in terms of value, but for some countries like Cameroon and Ghana, trade in forest products represents $15-48 \%$ of export value. Africa's share of sawn-timber production remains at $5 \%$ of the 41 million $\mathrm{m}^{3}$ produced by ITTO member countries, while the Asian region accounted for $62 \%$ of that total (FAO, 2000). The countries of North Africa (i.e. Algeria, Morocco, Egypt, Libya and Tunisia) accounted for $60 \%$ of the continent's wood imports in 1994. However, there is scope for more intra-African trade in wood products with countries south of the Sahara. South Africa alone accounted for $73 \%$ of the continent's production of wood pulp. With the 
exception of Kenya, South Africa, Swaziland, Tanzania and Zimbabwe, all countries in subSahara Africa import nearly all of their paper requirements. The purpose of this paper is to identify the opportunities and prospects for the development of the wood product trade under the New Partnership for Africa Development (NEPAD).

\section{Historical background of wood product trade in sub-Sahara Africa}

Prior to the colonial era in the sub-region, harvesting of logs was done manually for domestic purposes such as building, construction of bridges, woodcraft and fuel wood. With the advent of colonialism, harvesting of logs was carried out to supply the imperialists' wood requirement for tropical timber, which were found to be large in size and suitable for various uses. Most of the wood harvested was used for ship and boat construction, railway sleepers and bridge construction. These eventually opened up the region to larger markets because haulage and conversion of logs to sawn wood and exchange in barter trade started. Harvesting was more intense along the coastal regions as it was easier to float logs for water transportation than engaging in pit sawing which is more laborious. When British merchants started to procure tropical timbers the empire-grading rule were introduced and the cutting pattern were dictated in terms of size, allowance and quality grades. Sawing was generally done using circular saws during this period. Later, the use of band saws was introduced to improve quality of sawing and reduce large oversize logs, which are mainly to the advantage of the British merchants. Colonialism exploited the African continent; rapid decolonization with no planned transition to free trade introduced a vacuum, which was filled in many cases by non-decisive governments. The driving force among those involved in logging and sawmilling business was to make as much money as possible in the shortest possible time (Engku, 1997). Thus, both log and sawn timber were export driven while only rejected timber was left for domestic consumption.

\section{NEPAD and improvement in wood products trade}

The New Partnership for Africa's Development is a collective action by African states with the main objective of addressing the continent's lack of development. It is designed to establish conditions for the continent's increased integration into the global markets. It is focus on solving the problems of weak and incapable states by creating political consensus to support economic growth and poverty reduction, establish a stable environment for economic activity of firms and households. One of the key strategies to achieving these objectives is to strengthen regional cooperation and integration to increase cross-border trade and investment within Africa, as well as improve international competitiveness through the pooling of African resources. To achieve this, priority sectors are planned to be improved base on sustainable long-term development. The priority sectors identified are infrastructure, information and communication technology, human development and poverty reduction, health, education, agriculture, promoting diversification of production and exports, focusing on market access for African export to industrialized countries.

Trade deficit as a result of industrial wood product import by African countries is alarming, the region's bulk of tropical hardwood export not withstanding. The deficit is largely due to import by countries north of the Sahara that are not endowed with forest resources. Development of trade links could improve benefit to member countries from the use of their timber resources. It would lower their dependence on external supply of wood products and help to save scarce foreign exchange.

\section{METHODOLOGY}

This study derived from a survey designed to assess quality, trends and status of forest industries in Ghana, Nigeria and Cameroon (Akande et al., 2006). Data used for the study were obtained through the use of a structured questionnaire. The questionnaire was on types of products, product output, prices, marketing channels, trade partners, ownership structure. 
121 firms were surveyed in Ghana, 258 in Nigeria and 138 in Cameroon. Additional data were extracted from FAO publications. These sources were supplemented with information from International Tropical Timber Organization (ITTO). Physical observations of mills and on-the-spot assessment were used to validate information obtained from various sources.

\section{RESULTS}

\section{Structure of the Wood Products Trade}

The wood based industry in sub-Sahara Africa contributed to the mainstay of the economy of the region in terms of Gross Domestic product (GDP), export earnings and employment generation. Marketing of wood products are important to the countries because earning from such exports are used to finance development programmes. Markets exist whenever buyers and sellers are in touch with one another. The countries to which the wood products traded are located in European Union, North America, Asia and South-East Asia, Middle East, North and South Africa and the ECOWAS sub-regions (Table 1). The three countries export most of their products except Nigeria, which exports only furniture components, and this is mainly done by shipping by road transport within African countries.

There are different markets for the wood products. These are producer-consumer markets, local assembly markets and export markets. Producer-consumer markets are those where producers sell directly to the consumers. This is sometimes the case with furniture industries and poles. Consumers make direct orders. Local assembly markets are usually located near firms and are usually open space or stores where products are displayed on daily basis. Products like sawn wood and plywood fall into this category. The export markets are strictly for semi-finished and finished wood products, they are usually based on orders and emphasis is on better quality and reliable delivery. The market here is specialized and requires production of goods that can compete with other producers from other region.

The trading partners for wood products from the surveyed countries are shown in Table 1. Only Cameroon trades with the United State of America (USA). Information shows that the regulatory process, which products have to pass through in the USA, is too rigorous for sub-Sahara wood products. However, there are emerging opportunities provided by the African Growth and Opportunity Act (AGOA) of America, which are directed towards increasing trade with sub-Sahara Africa.

\section{Timber Products and Forest-based Industries}

The wood industry has a broad product mix, comprising sawn wood, veneer and plywood, particleboard, match splint, pulp and paper, transmission poles (Table 2). Sawn wood is the most diversified and it serves as raw material for the production of furniture and furniture components, floor parquets and other secondary wood products. The manufacture of tertiary wood products is gradually featuring in the three countries. Export of wood in unprocessed form is currently banned except in Cameroon where few log export is traded. There is a recent trend towards restricting exports of non-kiln dry woodfromGhana.

Table 1: Trading partners of the surveyed countries

\begin{tabular}{cll}
\hline Country & \multicolumn{1}{c}{ Sub-Sahara } & \multicolumn{1}{c}{ Others } \\
\hline GHANA & Senegal, Nigeria, Mali, & North America, Asia, South- \\
& $\begin{array}{c}\text { Niger, Sierra Leone, Angola, } \\
\text { Benin and Togo }\end{array}$ & $\begin{array}{l}\text { East Asia, Middle East, North } \\
\text { and South Africa }\end{array}$ \\
& &
\end{tabular}

\begin{tabular}{lll}
\hline NIGERIA & Cameroon, Niger, Togo, & Italy, Germany, United \\
Benin, Mali & Kingdom, South Africa, China, \\
& Egypt, Libya, Tunisia, Japan, \\
& France \\
& \\
\hline
\end{tabular}


CAMEROON Congo, Central African Republic Garbon, Nigeria, South Africa
France, Belgium, Spain, Italy, Japan, USA, China, Portugal, Kuwait, Asia, Germany, South Korea Canada, Holland, Egypt, South Africa,

Morroco,

Table 2: Structure and characteristics of the forest industry in the sub-region

\begin{tabular}{lll}
\hline Mill Category & Main Activity & Products \\
\hline Primary Mills & Logging & Logs \\
& & \\
Secondary Mills & Illegal-Chain Sawing & Flitches \\
& Sawmilling & Sawn wood \\
& Lumber drying & Air \& kiln dried lumber, \\
& Veneer milling & Rotary and sliced veneer, \\
& Ply milling & Plywood \\
& Treated Poles & Poles \\
& Pulp and paper & Newsprints, paper, toilet rolls \\
& Match production & Splints and matches \\
& Particle board & Wood board, wood-cement board \\
& Furniture \& Joinery Moulding & Furniture parts, Mouldings \\
& Flooring & Floorings \\
& Toy carving & Toys \\
& Doors & Doors \\
& Wood based panel & Particle board, cement-board
\end{tabular}

Source: Akande et al., 2006

Export levy concession is given to industries trading in kiln dry wood, as against the situation in Nigeria and Cameroon where unseasoned wood flourish in the market. $90 \%$ of the logging companies belong to expatriates in Cameroon. Expatriates undertake all major marketing operations. In Nigeria and Ghana, there is gradual incursion of foreign direct investment through the indigenous companies by their foreign trading partners.

Sawn wood: This remains the most prominent of all wood product trade. A lot of people are engaged in production and trade because of the quick profit return on investment with little risk unlike the secondary processing for export. This product forms the raw material base for the secondary processing industry intended for the export market.

Pulp and paper: The present situation from the study reveals that the 3 government owned factories in Nigeria had shut down with no hope in sight for reactivation except through privatization. The pulp and paper factory in Ghana is yet to take off. The mills, if put in operation, have the capacity to meet Africa's paper and paper products needs. Unfortunately, a lot of small-scale paper converting ventures that depend on the mills for raw materials have also been shut down.

Matches: There are presently five safety match industries in the countries surveyed one each in Cameroon and Ghana and three in Nigeria. These are inadequate for the requirements of the region for match supply. Nigeria used to have eight match making factories but a majority of these have closed down due to the influx of various imported brands of matches from Asian countries and the inability of the home industries to compete price wise. 
Veneer and Plywood: Capacity utilization is low coupled with aging machines, unavailability and high cost of raw materials. The operation of the mills has reduced drastically with some already shut down in Nigeria. Hence, there are importations from Ghana to Nigeria to meet the domestic demand.

Furniture \& Furniture parts: Wooden furniture parts and components are now manufactured and exported by the three countries. There are a lot of foreign direct investments (FDI) in this area due to favorable trade policies. Table 3 highlights some of these policies. The furniture industries are mainly found in most urban and semi-urban areas where ready markets exist for their products; there are a few larger ones producing very good furniture, which can compete in the international markets. The improvement in quality is as a result of a ban on importation of furniture items by the government of the three countries.

Wood species traded

The forests in the south of the Sahara are very rich in tropical timber species but a few of them are traditionally exported over the years. The exported one has dwindled and some are even threatened while others are going into extinction. The technical qualities documented over the years are used to determine the species exported. For conservation purposes, countries concerned have banned some woods in these categories. The present study identified the species listed in Table 4. It shows that the Mahoganies, Iroko and Obeche still form the bulk of the wood species traded. There is a growing interest within the Ghana timber industry to further process lesser-used species (LUS), considering the fact that most of the traditional species are largely depleted. Statistics shows a growing trend in the species composition in favour of LUS. For example, in 1989, 62 LUS species were exported as against 82 species in 2001. Ghanaian companies have also started processing rubber, wood, bamboo and coconut.

\section{Wood Product Trade and Policies}

International, regional, national environmental conditions, policies and regulations influence the market access and competitiveness of individual producers of wood products and thus affect trade flows. According to Law 34/01 of January 20, 1994 of Cameroon, any logging company is allowed to export $30 \%$ of logs harvested during the five years following granting of a concession. After the five-year period, $100 \%$ of export timber must be locally processed. However, lesser-known species may be exported as logs for promotion in the international market. The industry in Ghana in 2002 and 2003 pursue a gradual shift from the export of air-dried sawn wood to the export of kiln-dried 
Table 3: Summary of forest policies in place as related to forest industries in Cameroon, Ghana and Nigeria

\section{Cameroon}

-Forest concessions granted with the obligation to establish industrial processing units

-Establishment of a Directorate for the Promotion and Processing of Forest Products in 1998, with the following mandate: develop and implement a timber marketing policy, promote modern timber-processing crafts and techniques, followed by timber processing and exporting unit activities

-Development of an investment code (1990)

-Development of an industrialization master plan (1990)

-Adoption of an investment charter (2000)

-Introduction of an industrial free zone scheme as a major industrial incentive instrument (in 2000 , out of 44 companies registered in the Scheme, 33 belonged to the forest industry)

-Export quotas Progressive surtax on log exports Law 94/01 of 20 January 1994 regulating forestry, fauna and fisheries

-Establishment of a standardization and quality unit responsible for drafting national standards (Decree $\mathrm{n}^{\circ} 98 / 313$ of 9 December 1998) Establishment of a timber promotion centre for training and the promotion of lesser-known species (since 1970)

-First draft of the government bill on the Republic of Cameroon Investment Charter (2000)

-Law No 96/11 of 5 August 1996 on standardization, and the establishment of 20 technical committees responsible for developing standards, including a committee on timber, Silviculture and environment

\section{Ghana}

-PNDC Law 116, The Ghana Investment Code of 1985, to provide general incentives, benefits and concessions to entrepreneurs and investors, and special packages for specific sectors such as manufacturing. These include granting firms and investors full exemption for customs import duties on plant, machineries, equipment and accessories required for the enterprises

-Timber Resources Management Act (\& Regulation in 1999) Introduces timber utilization rights and Social Responsibility Agreement

\section{Nigeria}

-Log export ban since 1976

-Sustainable management of state reserved forests

-Improvement of timber recovery in secondary processing units

-Various incentives aimed at industries producing finished and semi-finished products

-Forest-sector recovery strategy through a revision of the law and forest industry support action

-Promotion of reforestation

\section{Source: ATO, 2000}


Table 4: Ten most exported timber species in the countries

\section{Country Commercial timber species exported}

Triplochiton scleroxylon, Entandrophrgma Spp,
Tectonia grandis, Khaya Spp, Milicia excelsa,
Pericospsis elata, Guibourtia ehie,
Tieghemalla heckelii, Aningeria robusta
Mansonia altissima

NIGERIA

Milicia excelsa, Afzelia africana, Khaya spp,

Mansonia altissima, Tectona grandis, Entandrophragma spp, Gmelina arborea, Nesogordonia papaverifera, Lophira alata

\section{CAMEROON}

Entandrophrgma utile, Entandrophrgma cylindricum

Erythrophleum spp Triplochiton scleroxylon

Milicia excelsa, Distemonanthus, Tectona grandis, Afzelia africana, Lophira alata

Source: Akande et al., 2006

Sawn wood, a result of the implementation of the Trees \& Timber Amendment Act of 1994. This Act imposes export levies on some selected species if exported air-dried has been successful in encouraging kiln-dried sawn wood exports from Ghana. Ghana also operates import free levy of wood from Gabon and Cameroon. In Nigeria, the government placed a total ban on round wood (unprocessed log) except for Gmelina wood due to its current market problems. The major components of current wood export from Nigeria are furniture components.

\section{Impediments to Sustainable Wood Trade Development Economic constraints}

Many Sub-Saharan countries are also currently undergoing economic transition. The Structural Adjustment Programs (SAPs) have resulted in the devaluation of national currencies, leading to erosion of the people's purchasing power and relative impoverishment of rural as well as urban populace. Under SAP, subsidies on commodities such as petrol, diesel and kerosene have been removed, and yet many firms rely on power supply from national grid, which results in downtime with devastating repercussions on production cost.

The inadequacy of financial resources for the wood based industry sector in the region is a real constraint on the ability and impact in global trade. The industries require substantial financing, which the poor economies of many countries can hardly afford, particularly in acquisition of new technologies and machinery to add value to their production. Hence, foreign direct investment (FDI) and international public sources of funds are needed. The UNCED document, Chapter 11 of Agenda 21, estimated that the total investment funds needed to achieve sustainable forest management (SFM) in developing countries would be about $\$ 31.25$ billion for the period 1993 to 2000. The current level of the Department for International Development (DFID) funding in forestry is only $27.2 \%$ of this amount, African countries are facing sharp declines in DFID funding for forestry programs. Moreover, there are a few appropriate financing mechanisms available for small and medium secondary timber-processing production enterprises. 


\section{Political instability}

Frequent changes of government in this region pose grave problems, and have direct and often overriding consequences for development locally and through foreign investment. No sane person will invest in an unsafe climate. FAO (2000) noted that the growing number of displaced people due to political conflicts and military struggles ravage forest resources even beyond national boundaries. Examples are the Sierra Leone and Liberia civil wars.

\section{Technical capacities}

The forest industry is characterized by outdated, often ill-maintained equipment, with low efficiency and lack of seasoned production manpower to manage the industry secondary timber-processing enterprises. Striking examples are the Nigeria pulp and paper mill at Iwopin and the Nigerian Newsprint Manufacturing Co. at Oku-Iboku, which have shut down for many years due to mismanagement and bad leadership. These mills would have helped reduce the trade deficit of African nations because they have installed capacity that can substantially meet Africa paper product needs. The Nigeria Plywood industry is equally bedeviled by similar problems.

\section{Product Certification}

Forest products certification is becoming an important tool for ensuring a sustainable management of forest resources. Forest product certification requires that a finished wood product carries a mark or identification by which the product can be traced to the sources where it is manufactured and even the source of raw material. It is a known fact that most African forest are not sustainably managed; this may pose a great barrier to wood product trade in the export market if urgent measures are not put in place to address the pertinent issues.

\section{Strategies for the Development of Wood Products Trade Trade facilitation}

The Ministerial Committee of Africa Timber Organization (ATO) noted that trade between African countries could be facilitated by the removal of barriers to trade such as those posed by tariffs (between monetary zones) and infrastructure (or the lack of it). Standardizing the framework of such trade is one of the objectives of regional organizations such as the Central African Economic and Monetary Community (CAEMC), the Economic Community of West African States (ECOWAS) and ATO. With the formation of NEPAD, development of interstate trade in Africa would allow for a better expression of comparative advantage of each of the member countries, which could lead to the establishment of a policy of cooperation and regional development based on the restructuring of trade. Increased direct trade of sub-Sahara countries with Maghreb countries such as Egypt, Algeria and Libya would help change the current trade flows, which are currently dominated by countries in Europe.

\section{Harmonization of forest policy}

Comprehensive forest policy at national levels and strategic framework at regional level are necessary to achieving sustainable wood product supply. The harmonization would provide support to countries in better defining priority lines of regional actions plan for national benefit, based on comparative advantages and identification of policy issues whose success in one country depends on collaboration and support from the others.

\section{Privatization}

The Millennium Development Goal (MDG) advocates that the credibility and technical capacity of public institutions need to be re-enforced in order that they may fulfill their mandates within the new trends of participation, decentralization and privatization. Evidence abounds to show that public enterprise solely managed by the government is a failure in Africa. Privatization provides a very pragmatic way of reviving some of the shut 
down mills because no reasonable investors would accept their investments being washed down the drain.

\section{DISCUSSION}

Wood product market in sub-Sahara Africa is large and fast growing, export has been constrained mainly by factors such as poor quality of finished products which is as a result of modern technology and skills in wood processing mills; lack of information technology to access overseas market information and government policies which are inconsistent with global trends. Timber rich African countries export largely semi-processed wood as a means of earning foreign exchange, while they import industrial wood products, which offset all foreign exchange earned and still give them trade deficits. Africa still suffers from weak infrastructure and environmentally demanding export markets that constrain major investments in wood processing; production of export oriented market is however on the increase due to log export ban. Value-added and labour absorptive capacities of the wood processing plants are not fully utilized in upstream production due to inability to produce quality products; failure to meet delivery orders and inadequacy of momentum to sustain the product chain. The gains from downstream processing are inexhaustible if embraced. The wood industry sector can only survive in the competitive world market if efforts are geared towards improving quantity and quality of products and also providing an enabling environment for foreign direct investment for sound industrial development.

Forest industrial reforms in Africa should focus on the following to increase their trade: use of wood waste such as sawdust to produce particle board and cement-board should be step up; the use of solid waste such as barks and off cuts as is the present situation in Ghana where they are used in kiln dryer should be further encouraged. The use of lesserknown species should be linked with product development as a means of demonstrating their potentials to increase the number of exportable wood species. Energy supply is a major incentive for industrial development in Africa; it determines the level technology and degree of efficiency of production. It is recommended that power generation using reject logs and mill residues should be considered seriously to supplement public supply, which in most cases is unreliable.

\section{CONCLUSION AND RECOMMENDATIONS}

The wood product trade could be improved and be made more efficient when complemented with market information intelligence that facilitate regular market information on current timber situation, supply of only well seasoned wood products, privatization of publicly owned firms in the industry to improve management for better results, improvement of infrastructures such as electricity, telephone, roads and internet services for facilitating marketing and distribution of forest products. Forest product certification is a factor that is seriously constraining most of the export trade in wood product to most countries in Europe. This can only be improved if forestry industries can show that their products originate from sustainably managed forests. The current trend assessment showed that tropical timbers are not meeting the eco-label requirement. Consequently, a boycott is imminent if this issue is not urgently addressed.

\section{Acknowledgements}

The authors appreciate the financial contribution and permission of the African Forestry Research Network (AFORNET) Nairobi, Kenya to carry out and publish this work. 


\section{REFERENCES}

Adeyoju, S.K (1975): Forestry and the Nigerian Economy.

Akande, J.A., Adu-Anning, C., Ntabe, E., Agbeja, B.O. and S.L. Larinde. (2006): Quality assessment of status and trends in forest industries of Ghana, Nigeria and Cameroon. Final Report to the African Forestry Research Network (AFORNET, Kenya). 150pp

Akande S.O \& Olokesusi F (1999): Impact of Eco-labelling on the export of Timber and Timber products from Nigeria. Final report. Presented at The African Economic Research Consortium (AERC), Workshop held at Accra, Ghana. May 29-June 3, 1999. pp4-20.

African Timber Organization (2000), Promoting further processing of tropical timber in Africa; Africa timber organization Ministerial Conference proposal for Action. pp19-21

Enabor, E.E (1976): Prospect for wood product trade under the Economic Community of West African State (ECOWAS). Nigeria journal of forestry 6(1\&2) pp 24-33.

Engku, A.R (1997): Current trends in downstream processing of wood based industry in Malaysia. In conference on forestry and forest products research proceedings pp 33-47.

FAO 2000: The challenges of sustainable forestry development in Africa twenty first FAO regional conference for Africa Yaoundé, Cameroon, 21-25 February 2000 http://www.photius.com/countries/ghana/economy/ghana_economy_forestry.html

Sources: The Library of Congress Country Studies; CIA World Fact book.

ITTO (2003): International tropical timber organization annual review and assessment of the world timber situation 2003.

Nwokeabia, O.D (1996), Forest products certification: A tool for sustainable forest resources trade and environmental management in Nigeria. Nigerian journal of forestry, vol.26 No.2 pp57-60.

Omoluabi A.C (1985): The Development of the Nigeria Particleboard Industry. Unpublised Ph.D Thesis, University of Ibadan.

Popoola, L. (1999): Forest Resources Study: Marketing and pricing policies component. FRS (Nigeria)- A FORMECU-ADB Study by BEAK Consultancy Ltd.

Popoola \& Adebusoye (2002): Economic analysis of Parquet production in Nigeria. Nigeria journal of Science Vol. 36 No. 2(2002) pp 141-148

RMRDC (2001) Multi-disciplinary task force report of the techno-economic survey on wood and wood products and furniture sector ( $3^{\text {rd }}$ update) August 2001.

Spears, J.S (1966): Forest investment from a government point of view. Paper presented at the $6^{\text {th }}$ World Forestry Congress, Madrid, Spain.

Westoby, J.C (1962): The role of forest industries in the attack of economic development. Unasylva 16(4) pp 168-201. 